\section{Den komplekse guldalder - kort fortalt}

af Lasse Horne Kjaldgaard, ph.d., direktor for Det Danske Sprog- og Litteraturselskab

"I forairet 2012 arrangerede Folkeuniversitetet en rakke såkaldte "Stjernestunder" $i$ samarbejde med Det Kongelige Bibliotek og Kobenhavns Universitet. Et af arrangementerne fandt sted $i$ Universitetsbiblioteket $i$ Fiolstrade $i$ anledning af bygningens 150 års jubilaum ${ }^{0}$ året for. I den anledning gav litteraturbistorikeren, ph.d. Lasse Horne Kjaldgaard, der d. 1. oktober 2011 efterfulgte professor Jorn Lund som direktor for Det Danske Sprog- og Litteraturselskab, et signalement af den periode, der efterfolgende er blevet kaldt "guldalderen".

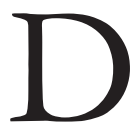
et går ikke godt. Statskassen er tom. Ja, den er ikke bare tom, men der er et stort hul i den.

Der er panik på finansmarkedet. Inflationen hærger. Der har været krig i årevis. Den danske stat har brugt alt for mange penge på militæret - og har fået alt for få penge ind på grund af svigtende handelsindtægter.

Sådan ligger landet - ved indledningen til guldalderen. Guldalderen begynder med bundløs gæld og nederlag og ydmygelse. Den begynder med Englandskrigene, hvortil hører det første bombardement af en civilbefolkning i nyere militærhistorie, nemlig med terrorbombningen af København i sep- tember 1807. Den begynder med statsbankerotten i 1813 og med afståelsen af Norge i 1814. I dag, hvor man ikke ser med milde øjne på imperialisme - altså på at man besætter og bestemmer over andre lande og folkeslag - må afgivelsen af Norge tage sig ud som et fremskridt. Men sådan oplevede man det bestemt ikke, da det skete.

I årene 1819 til 1821 rejste digteren og filosoffen Poul Martin Møller som skibspræst i Østen. I Manila hørte han konstant klerke og kræmmere gå rundt og sige: "Danmark er et lidet, fattigt Land". Og det var det jo - efter fallitten i 1813 og tabet af Norge i 1814. Men Møller var glad for Danmark, og han var ked af kendsgerningerne. Derfor provokerer det ham til at svare igen i digtet "Glæde over Danmark", der bruger råbet som omkvæd og fjerner kommaet til sidst, så han afslutningsvis i digtet kan takke Gud for at tilhøre et "lidet fattigt Land". ${ }^{1}$ Uden komma, det vil sige: et rigt land.

Poul Martin Møller er en af dem, der har æren for, at vi kan se tilbage på guldalderen som en guldalder. For der

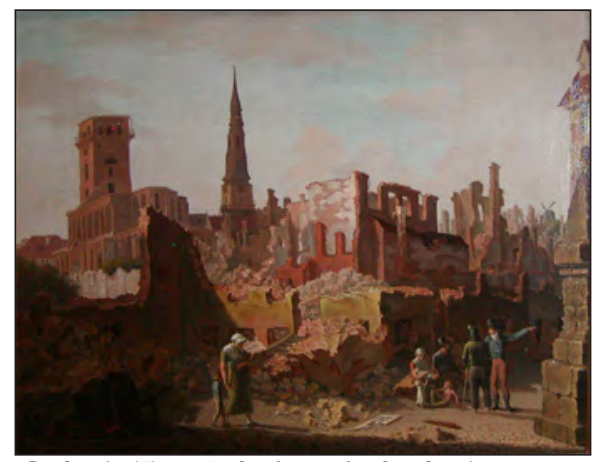

Gräbrodre Torv $i$ Kobenhavn efter bombardementet 1807. Malet af J.P. Moller i 1808 efter samtidig tegning. 
var bestemt intet gyldent ved den til at begynde med. Guldalderen blev til en guldalder, ikke først og fremmest på grund af store politiske, militære eller økonomiske bedrifter. Men snarere på grund af de store mængder af fremragende og usædvanlig levedygtig kunst inden for alle arter - litteratur, musik, billedkunst - der blev frembragt samt de store og slidstærke tanker inden for filosofi og forskning, der blev tænkt og fældet ned og sat i omløb i 1800-tallets første halvdel.

Selve ordet "guldalder" er ladet med den følelse, som vi i nyere tid er begyndt at kalde for nostalgi, det vil sige idealisering af eller ligefrem længsel efter en svunden tid. Guldalderforestillingen kommer fra græsk historieskrivning, hvor bl.a. Hesiod bruger ordet om den ældste og lykkeligste tid, der efterfølges af henholdsvis kobber- og jernalder. De mindre ædle metaller betegner mindre lykkelige perioder. Ordet "guldalder" har man siden hen brugt som en kvalitetsbetegnelse inden for mange nationale traditioner og som etikette for mange historiske epoker. I almindelig dansk historieskrivning taler man for eksempel også om velfærdsstatens guldalder, fra 1950 til 1980. Men guldalderen i bestemt form er - plejer man at sige - lig med første halvdel af 1800-tallet.

Nu er det jo ikke ualmindeligt, at man først finder på navne til historiske perioder, efter de er forbi. Faktisk får epoker som regel deres navn af eftertiden. Barokkens digtere kunne ikke vide, at de var barokpoeter; og de tidligste modernister begreb ikke, at de var modernister. Sådan cirka er det også med betegnelsen "guldalderen". Guldalderkunstnerne gik ikke rundt og kaldte sig selv sådan - ikke fordi de ikke var glade for sig selv, men fordi de ikke kunne vide, at det var det, de var, altså guldalderkunstnere. Inden for litteraturen blev guldalderbetegnelsen etableret af litteraturhistorikerne Valdemar Vedel og Vilhelm Andersen $i$ slutningen af 1800-tallet, mens den inden for kunsthistorien først fangede an fra 1960'erne og frem. "Sådan cirka", skriver jeg, for det er en sandhed med modifikationer. Ordet "guldalder" optrådte også i guldalderen. I en anmeldelse i 1843 skrev Johan Ludvig Heiberg for eksempel: "Vi leve ikke mere i Guldalderen, men, som bekjendt, i Jernalderen, og, mere bestemt udtrykt, i Jernbane-Alderen". 2 Året efter åbnede nemlig Danmarks første jernbanestrækning, Altona-Kiel-banen. Også den side af moderniteten, massetransporten, var ved at blive lagt på skinner.

Bogen, som



Heiberg anmeldte, var ikke et hvilkensom-helst værk, selv om han skrev om den med ironisk ophøjethed eller - om man vil - nedladenhed. Det var tobindsværket Enten-Eller, udgivet af pseudonymet Victor Eremita, som var en litterær maske for Søren Kierkegaard. Søren Kierkegaard satte med sine skrifter gang i en isme, som har bredt sig ikke bare i filosofien, men også i populærkulturen i efterkrigstiden, 




Tre danske verdensberomtheder i guldalderen: H.C. Andersen, H.C. Ørsted og Bertel Thorvaldsen. nemlig eksistentialismen. Det er et oplagt eksempel på det efterliv, som guldalderens lokale litterære begivenheder har fået - ikke bare i Danmark, men worldwide. Det gælder i indlysende grad også H.C. Andersen, som Søren Kierkegaard indledte sin forfatterkarriere med at mobbe - med omfattende litterære konsekvenser.

Kierkegaards første bog er også den første bog om H.C. Andersens forfatterskab, nemlig Af en endnu Levendes Papirer fra 1838. Undertitlen på den er Om Andersen som Romandigter, med stadigt Hensyn til hans sidste Vark, 'Kun en Spillemand', og dens filosofisk underbyggede budskab er, at Andersen er en dårlig romandigter. Kritikken tog Andersen til sig i den forstand, at han de næste ti år ikke skrev en eneste roman, til trods for at det var den genre, som han var brudt igennem med. Til gengæld kastede han sig over kortprosaen og skrev de godt halvanden hundrede eventyr og fortællinger, som han i dag huskes for. Hvilket altså blandt andet kan tilskrives et skub - kærligt eller ukærligt
- fra Søren Kierkegaard.

H.C. Andersen og Søren Kierkegaard levede og skrev på samme tid i guldalderens København - sammen med en lang række andre store videnskabsmænd og kunstnere. Udefra set var der tre danske verdensberømtheder i guldalderen: H.C. Andersen, H.C. Ørsted og Bertel Thorvaldsen. Og her taler jeg altså om den samtidige modtagelse, ikke om eftertidens, for der er kommet flere til. Købstaden var fuld af genier. For eksempel sprogforskeren Rasmus Rask eller balletmester Bournonville eller Københavnerskolen inden for malerkunsten, med C.W. Eckersberg i spidsen. Hver for sig er disse skikkelser store og betydningsfulde nok til at betegne en periode. Når der nu er så mange af dem, må de deles om en periodebetegnelse: guldalderen.

Som sagt er det på grund af dem - og den kunst og videnskab, de bedrev - at guldalderen i dag erindres som en guldalder. I eftertidens billede fylder de to virkefelter så meget, at man godt kan glemme, at der overhovedet foregik 




Den Grundlovgivende

Rigsforsamling behandlede og vedtog Junigrundloven af 1849. Den forste Grundlov blev underskerevet 5. juni 1849 af Frederik 7., bvormed styreformen i Danmark andredes fra enevalde til konstitutionelt monarki. Maleri af Constantin Hansen, 1861-1865. Frederiksborgmuseet.

andet i guldalderen. Men det gjorde der. Grunden bliver i guldalderen lagt til Danmarks nuværende styreform. Det er i de år, at man begynder at tage skridt i retning af enevældens afskaffelse og folkestyrets indførelse, stadfæstet ved Junigrundloven af 1849.

Folkestyrets første svære år har historikeren Hans Vammen netop udgivet en bog om, Den tomme stat. Den tager udgangspunkt i et berømt og meget stort maleri af Constantin Hansen - Den grundlovgivende forsamling - der blev bestilt af Orla Lehmann i 1860, som en tilbageskuende idealisering af begivenheden. Om dette maleri findes også en hundrede år ældre bog, Mandene fra 48 , af den politiske historiker Erik Henrichsen, som indledningsvis gør opmærksom på de forskellige guldaldre, som fandtes $-\mathrm{i}$ guldalderen:

Trods alle ydre Ulykker, som har ramt vort Fædreland i det 19de Aarhundrede, maa dette Aarhundrede dog kaldes den egenlige Guldaldertid i Danmark [...] Med Oehlenschlæger og hans Tid fik vi en poetisk Guldaldertid, med Grundtvig og Søren Kierkegaard fik vi en religiøs Guldaldertid, og med den Række af Personligheder, der i Fyrrene traadte frem paa den politiske Skueplads, fik vi ogsaa en politisk Guldaldertid ${ }^{3}$

Henrichsens fremstilling af guldalderen er mere kompleks end den gængse. Han deler den op i forskellige dimensioner: den poetiske, religiøse og politiske. At den sidste dimension er kontroversiel, ved han godt, og det er årsagen til, at ordet "politisk" er spatieret i indledningen. Mest af alt er bogen nemlig et bravt forsøg på at vise betydningen af den nationale-politiske vækkelse i 1830 'erne og især i 1840'erne, der kan berettige, at man også benævner tidsrummet som en politisk guldalder.

De tre guldaldre, Henrichsen nævner - den litterære, den religiøse og den politiske - svingede ikke harmonisk med hinanden. Slet ikke. De færreste fremtrædende forfattere og kunstnere delte de politiske reformønsker, som ledte op til Junigrundloven. For Kierke- 


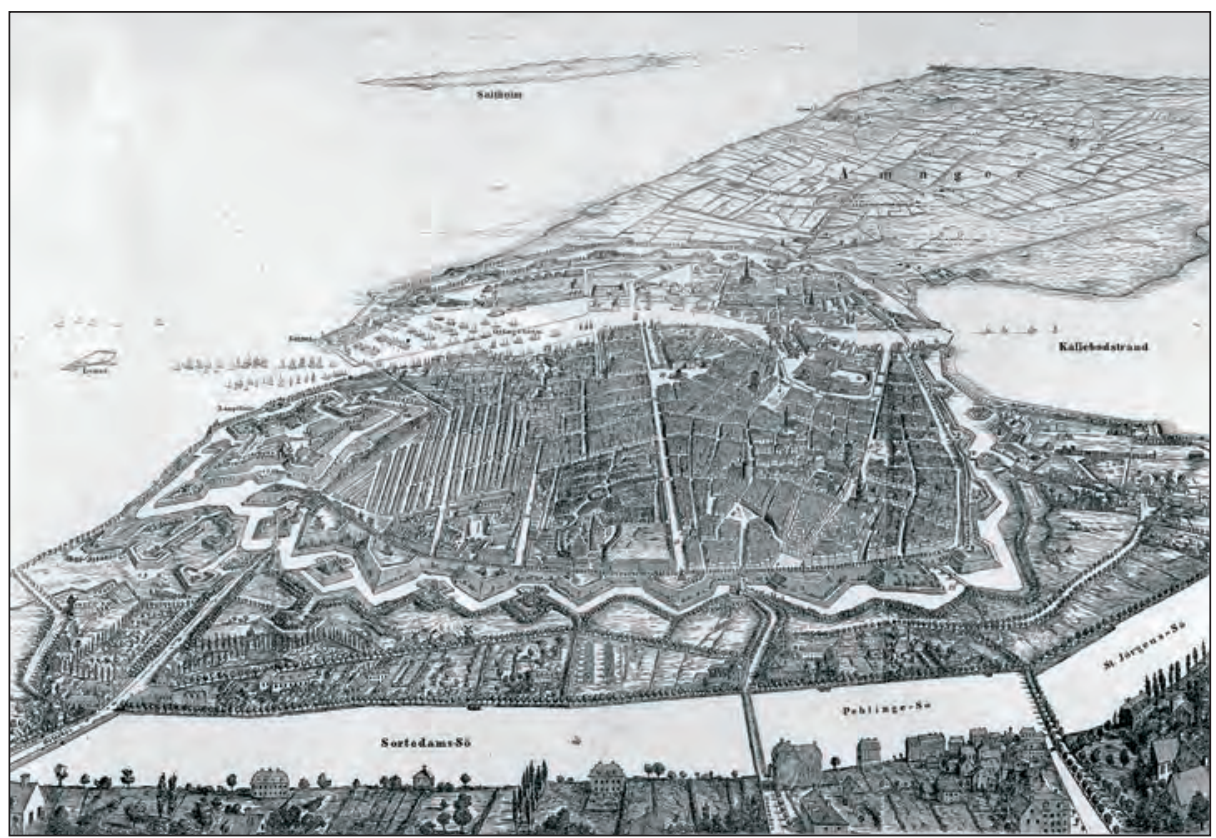

Kobenhavn i fugleperspektiv ca. 1851-70. Det var ingen stor by.

gaard var politiseringen bedrøvelig, og han bekæmpede den igennem hele sit forfatterskab, der gjorde kristendom til kulturkritik. At det gik, som det gjorde, var bestemt ikke noget, Kierkegaard brød sig om. Demokratiet var, skrev han under pseudonym i Afsluttende uvidenskabelig Efterskrift fra 1846 "den meest tyranniske Regjeringsform", for den "forpligter Enhver til positiv Deeltagelse". ${ }^{4}$ Skal man formulere det venligt, kunne man sige, at Søren Kierkegaard, som alle sande gentlemen, kun forsvarede tabte sager. Men også de tabte sager - den store modstand mod demokratiet ikke mindst - er vigtig at få med i billedet af guldalderen. De godtgør, at forholdet mellem de forskellige guldaldre - den litterære, den religiøse og den politiske - var ét, der slog gnister.

Der er måske ligefrem én af grun- dene til, at guldalderen overhovedet kunne lade sig gøre? For det er og bliver jo en gåde, hvordan så mange talentfulde kunstnere, forfattere og forskere kunne udfolde sig på samme tid i samme lille by $i$ et forarmet nordeuropæisk land, på afstand af tidens kulturelle og videnskabelige centre - langt væk fra, hvor det skete. Hvordan var det muligt? Det kan der gives flere forklaringer på. Her vil jeg nøjes med tre, hvoraf de to første tilsyneladende - men kun tilsyneladende - modsiger hinanden.

Den første er, at guldalderens intellektuelle miljø var så lille og lukket. Københavns grænser gik ved voldene, og det var inden for disse, at alting foregik, med et intellektuelt centrum i universitetet på Vor Frue Plads. Fysisk befandt man sig meget tæt på hinanden, og det gjorde man 
også i den intellektuelle offentlighed. Man fulgte med i hinandens arbejde, læste hinanden og reagerede ofte på hinanden. Den polemiske energi var voldsom, og det var bestemt ikke kun Heiberg og Kierkegaard og Andersen, der skubbede til hinanden. På den måde udgør guldalderen et intellektuelt og tekstligt netværk, som man skal kende for at kunne afkode tidens skrifter. Som allerede nævnt kaldte Kierkegaard sit første pseudonym for Victor Eremita, den sejrende eneboer, og det kan forlede en til at tro, at han arbejdede $\mathrm{i}$ idel afsondrethed. Og det gjorde han også i en vis grad i fysisk henseende, men i intellektuel forstand var han i tæt dialog med en stor skare af samtidige skribenter i guldalderen.

Den anden forklaring er, at guldalderens intellektuelle miljø var uhyre åbent og internationalt orienteret. Alle nævnte skikkelser - på nær Kierkegaard - rejste meget $\mathrm{i}$ andre lande og holdt sig hele tiden ajour med udenlandske tanker og tendenser. Ja, det gjorde Kierkegaard bestemt også, selv om hans egne internationale erfaringer begrænser sig til nogle få ture til Berlin. Berlin var netop det intellektuelle kraftcentrum for guldalderens forfattere, og hvad der foregik dernede, kunne man også følge med i via boghandlerne i København. I den forstand var grænserne åbne, og det var også - vil jeg skynde mig at tilføje - faggrænserne. Hvor placerer man tænkere som Kierkegaard eller Grundtvig, eller en naturvidenskabelig forsker som Ørsted, der både var fysiker og filosof? Hvor hører de hjemme i forhold til vor tids viden- skabelige kategorier og videnskabelige institutioner?

Den tredje forklaring er, at guldalderen er en periode, hvor store fortolkningssystemer og forventningshorisonter stødte sammen. Man tænkte og skrev under et uhyre pres - med en stærk bevidsthed om, at man befandt sig i en omvæltningstid, hvor man var på vej ud af én epoke og samtidig stod på tærsklen til en ny. At man levede i en mellemtid, med andre ord. I guldalderen - ikke mindst i 1830'erne og 40'erne - vrimlede det med store fremtidsvisioner, politiske, filosofiske, religiøse og æstetiske. Der findes en glemt nøgleroman af Henrik Hertz fra 1839, der hedder: Stemninger og Tilstande: Scener og Skildringer af et Ophold $i$ Kjobenhavn, hvori hovedpersonen på et tidspunkt begejstret udbryder: "Vi leve i Anticiperingens Tid". 5 Sådan føltes det netop. Og især på det politiske område voksede forventningerne til fremtiden sig store, Soren Kierkegaard (1813hvilket affødte 1855), tegnet af Peter megen skepsis Klastrup.

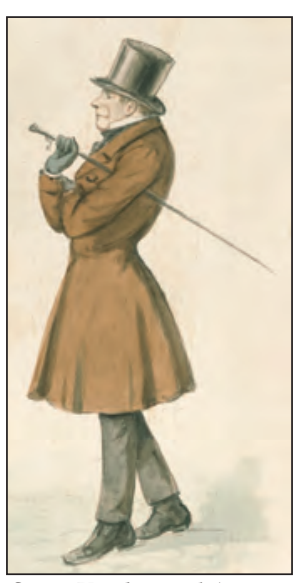
hos de store forfattere. I En literair $A n$ meldelse fra 1846 skriver Kierkegaard: "De store og gode Handlingers Tid er forbi, Nutiden er Anticipationernes". ${ }^{6}$ I modsætning til den dådfuldhed, som var karakteristisk for revolutionstiden, var samtiden præget af anticipationer, fore- 
gribelser af hvad fremtiden måtte eller ville bringe.

Heller ikke Søren Kierkegaard betragtede sin samtid som en guldalder. Men det er den ikke desto mindre blevet til, og mit korte bud på guldalderens mulighedsbetingelser er altså: kombinationen af stor international orientering, på den ene side, og et lille kompakt, sammenfiltret, sladrende og intrigant københavnermiljø, hvor man animerede og inspirerede og irriterede hinanden, på den anden side, og så endelig at der

\section{Noter}

0 Om Universitetsbiblioteket i Fiolstræde se senest David Bretton-Meyer \& Jens Kirkeby Hansen: Det Kongelige Bibliotek. Universitetsbiblioteket Københavns Universitet Fiolstræde 1. 1997. 32 s. Ill.; og Erland Kolding Nielsen: "Nye funktioner i "Bøgernes Katedral", Arsberetning. Det kongelige Bibliotek, 1997, ss. 8-11.

1 Poul Martin Møller: "Glæde over Danmark", Tilskuerne. Et Ugeskrift, nr. 47, 1823, s. 374-376. var et gammelt samfund, som var ved at gå til grunde, og et nyt, der var ved at opstå. Det gik ikke stille for sig, og netop derfor er der også meget mere larm og bevægelse i guldalderen, end vi er blevet vant til at forestille os. Guldalderen var konfliktfyldt og så godt som en permanent krisetilstand. Tiderne var trange. Men over for kunst og videnskab var man ikke påholdende, hverken med agtelse eller økonomisk støtte. Heldigvis da, for ellers var guldalderen nok aldrig blevet til en guldalder.

2 Johan Ludvig Heiberg: "Litterær Vintersæd", Intelligensblade, nr. 24, 1.3.1843, s. 289.

3 Erik Henrichsen: Mandene fra 48, København, 1911, s. 7.

4 Søren Kierkegaard: Afsluttende uvidenskabelig Efterskrift. København, 2002, s. 563.

5 Henrik Hertz: Stemninger og Tilstande. Scener og Skildringer af et Ophold $i$ Kjobenhavn. København, 1839, s. 313.

6 Søren Kierkegaard: En literair Anmeldelse. København, 2004, s. 68. 